\title{
K-12 ONLINE LEARNING AND STUDENTS WITH DISABILITIES: PERSPECTIVES FROM STATE SPECIAL EDUCATION DIRECTORS
}

Paula J. Burdette

National Association of State Directors of Special Education

Diana L. Greer

University of Kansas Center for Research on Learning

Kari L. Woods

University of Kansas Center for Research on Learning

\begin{abstract}
K-12 special education policies and practices that ensure students with disabilities receive a free, appropriate public education in the least restrictive environment are coming under pressure from the rapid expansion of online learning. Forty-six state and non-state jurisdiction special education directors responded to a brief survey about $\mathrm{K}-12$ online learning. Findings demonstrated an increase in the number of states providing online instruction; indicated that students with many different types of disabilities participate in online learning; and described the directors' reflections on current issues as well as anticipated barriers to students with disabilities participating in online learning. Ambiguity and variability existed across state policies regarding online education as each state may have been in a different stage of adopting this relatively new approach to $\mathrm{K}-12$ education. As a result, students bring to their undergraduate education a wide array of perceptions, attitudes, and prior experiences that may affect their learning outcomes.
\end{abstract}

\section{KEYWORDS}

$\mathrm{K}-12$ online learning, students with disabilities, special education

\section{INTRODUCTION}

Undergraduate students' perceptions, attitudes, and prior experiences with online learning have significant relationships with online learning outcomes [1, 2]. The implication is that $\mathrm{K}-12$ online learning experiences will increasingly affect higher education online learning outcomes. Students with disabilities who participate in $\mathrm{K}-12$ online learning will have experiences with a variety of modification, accommodations, and related services afforded them through the Individuals with Disabilities Education Act (IDEA) of 2004 (P.L. 110-325) that may set expectations for higher education asynchronous learning networks. Therefore, institutions of higher education have a natural interest in the extent and nature of $\mathrm{K}-$ 12 online learning and students with disabilities [3].

\section{A. Growth in K-12 Online Learning}

Online learning - defined here as a program or course in which students receive all of their education over a networked system such as the Internet-is rapidly growing among K-12 students in the United States. Evidence of this growth is seen in full-time online school enrollments, which are four times what they were just a decade ago, with 275,000 enrollees in 2011-2012 [4]. 
Broad public awareness of online learning has changed in nature during the last decade as well. In 2001, a report on virtual school trends and issues referred to online learning as the "next wave in technology ... joining proven distance learning methods" [5]. By October 2011, the issue of quality in online learning was in the national news, and the media were asking whether the burgeoning market of $\mathrm{K}-12$ online learning providers was scoring higher for Wall Street or students [6]. Today, online learning exists in every US state as an alternative to traditional neighborhood schools, likely to never be considered as just another method of distance learning again.

If technologies continued to advance and underlying costs continued to decline, Christensen, Horn, and Johnson predicted that online learning would become a disruptive innovation that rapidly changes the face of $\mathrm{K}-12$ education [7]. However, disruptive innovation is neither abrupt nor immediate. Rather, disruptive innovation theory predicts that the substitution of an old method or technology by a new one (e.g., paper to electronic books; brick-and-mortar to virtual schools) starts slow, steepens dramatically, and finally asymptotically approaches $100 \%$ replacement - following an S-curve pattern of growth [7].

\section{B. Policies for Serving Students with Disabilities in the Online Environment}

Although online learning is far from a 100\% replacement for traditional schools and pedagogies, the pace of growth in online learning is accelerating and placing pressure on educational policies created for traditional school structures [8]. Indeed, a recent examination of the extent and nature of online learning in American K-12 education identified "a continuing need to establish and update state and local policies for funding, attendance requirements, and other issues related to online instruction" [9]. An important issue in this context is whether policies and practices continue to ensure that students with disabilities "receive all the educational benefits afforded by the technology in an equally effective and equally integrated manner" as required by federal law and regulation [10].

Higher education settings, where online learning is more prevalent than in $\mathrm{K}-12$ education, have been forerunners on the issue of students with disabilities. Because institutions of higher education are bound by accessibility laws (i.e., Americans with Disabilities Act and Rehabilitation Act Sections 504 and 508), several schools have already faced legal challenges that could be instructive for K-12 education. For example, in May 2012, students with disabilities at the University of Montana filed a complaint with the US Department of Education, alleging they faced discrimination [11]. The specific allegations included, among other things, inaccessibility of class assignments, materials, live chats, and discussion boards in the school's online learning management system and scanned images of documents on websites and in library databases that cannot be read by a screen reader. At this time, the university is preparing an electronic and information technology policy to address these technological barriers to online learning for students with disabilities. This lawsuit is just one of many in higher education that are compelling institutions to make online learning more accessible [12,13,14]. Therefore, $\mathrm{K}-12$ online learning environments have the opportunity to learn from these higher education experiences, with the prospect to more thoughtfully design systems and establish policies that ensure students with disabilities receive free and appropriate public education in the least restrictive environment, as required by IDEA.

\section{Previous Survey of State Directors of Special Education}

Even as issues related to students with disabilities in online learning mount, little has been reported in the professional literature about $\mathrm{K}-12$ special education policies and practices with respect to online learning. Therefore, special education educators, education researchers, and policymakers are working to document and understand the effects of online learning on students with disabilities and the legal rights and protections afforded to these students. For example, a 2009 report from Project Forum at the National Association of State Directors of Special Education (NASDSE) described mixed findings from a survey about $\mathrm{K}-12$ virtual public schools and students with disabilities that was administered to the 61 US state and non-state jurisdiction educational agencies (SEAs) [15]. 
Thirty-eight of the 61 SEAs responded to the NASDSE survey, representing a $62 \%$ response rate. Of the respondents, 15 had state-level virtual public schools and two more had such schools in the development stage [15]. From among the 15 states, 12 SEAs reported that their state virtual public school served students with disabilities, and 11 reported that their state provided policy or guidance for students with disabilities participating in these schools (see table 1 for categories of students with disabilities served). The SEAs reported some of the challenges they faced when serving students with disabilities in the virtual public school programs, including

- not being adequately prepared to serve students with disabilities,

- having to revise the curriculum to meet accessibility requirements,

- not being able to meet the needs of students with severe disabilities,

- lack of communication between the student's school of residence and the virtual public school,

- being able to ensure that students with disabilities were receiving sufficient support,

- providing sufficient numbers of support staff to be able to provide services to all enrolled students with disabilities, and

- lack of adequate funding.

\section{METHOD}

In light of the observed growth and predicted disruptive innovation of online learning, an updated report on state special education policies and online learning was warranted. Therefore in 2012, the 61 state and non-state jurisdiction directors of special education (hereafter referred to as states) were asked to complete a survey to investigate (a) the influences driving online learning in their jurisdictions, (b) the participation of students with disabilities in online learning, and (c) the issues concerning the provision of a free and appropriate public education in an online learning environment. The intention was not to replicate the previous 2009 NASDSE survey but instead to add contemporary data to the literature and observe whether changes were taking place in a few key metrics. Forty-six states responded to the electronically-administered survey from May through July 2012 (a 75\% response rate).

\section{FINDINGS}

\section{A. Moving Education Online: Primary Drivers}

In order to better understand what states regarded as the important influences related to the observed growth in online learning, the survey posed an open-ended question that allowed for multiple responses: What do you consider to be the primary drivers that are moving districts to more online instruction? All 46 states identified one or more driver, from among which three major themes emerged.

First, cost was a clearly identifiable theme as a driving force toward more districts offering online instruction, with half of the respondents $(n=22)$ mentioning cost, financial, funding, or budgetary concerns. For instance, they said that online learning was a cheaper alternative to direct instruction; that financial incentives existed for online learning and online learning programs can "offer more courses without additional cost for staff."

The second theme observed in the responses was flexibility of and alternatives to traditional scheduling and instructional methods, with 18 states citing this as driving the move to more online learning. They included terms such as "personalization," "individualization," "differentiation," and "choice" for parents and students when they discussed flexibility. Three of these states specifically mentioned the flexibility that online learning provides for credit recovery, high school completion, or dropout prevention.

The third frequently mentioned theme was access to courses or qualified teachers as a primary driver for 
districts to move more instruction online $(n=16)$. Five of these 16 states specifically mentioned access for students in rural areas, presumably locations where qualified teachers in specialty content are less available to local districts.

In addition to these larger themes, five states mentioned the increased access of the general public to technology as a driver that supports student access. One state mentioned that online education provides districts an opportunity to generate revenue; another state mentioned that improved services were a primary driver for districts.

\section{B. Students with Disabilities and Online Learning}

To understand more about the relationship between students with disabilities and online learning, the survey posed several questions, including a few key metrics to gauge changes since the NASDSE survey in 2009. First, states were asked the following: Does your state education agency provide any publicly available guidance for educators, parents, or students related to the provision of online education? Twenty-seven of the 46 states responded affirmatively; that is, they indicated that they provide publicly available guidance regarding online learning. Nineteen of the states indicated they did not provide this information to the public. Twenty-six states provided a web link enabling us to review this guidance. Only 17 of these websites mentioned provision of special education services in online environments. Guidance materials on these websites ranged in specificity from informing districts that they must write a policy that addresses accommodations for these students; to indications that teachers need to be responsive to Individual Education Program (IEP) accommodations; to specifying that during enrollment in an online setting, districts must not discriminate based on disability and may not ask parents to revoke their consent for special education services as a condition of acceptance into an online program.

The survey asked the states, does your state have data on which students with disabilities are receiving their instruction through an online environment? Less than one-quarter $(n=11)$ of the states responded that they were collecting this type of data. Five of these states said they were also collecting information on which students with disabilities were receiving instruction through supplemental online courses. Three of these states reported collecting information on students who received instruction in a blended model (combined face-to-face and online instruction).

The survey asked, does your state have data on which students with disabilities receive some or all of their related services through an online environment? Only four of the 46 states reported collecting data describing students with disabilities who were receiving a related service (e.g., speech language therapy, physical therapy) through an online model.

Similar to the 2009 NASDSE survey, all 46 states were asked to indicate which categories of disability were represented among participating students in any online environment (e.g., online program, supplemental course, or other blended programs). Even though most states at the time of the survey were not collecting data on specific numbers of students with disabilities who were receiving instruction in an online environment, 25 states were aware of the disability categories that were represented among students (table 1). Compared to the NASDSE survey, a greater proportion of responding states reported serving students in each category except visual impairment, where the proportion and number of states dropped.

Lastly, only three states of the 46 provided information about the percentage of students with disabilities who were receiving instruction through any online programs. Given this limited response, these data do not provide a reliable prevalence rate for students with disabilities in online learning. 
Table 1. States that served online instruction reporting disability categories

\begin{tabular}{|l|c|c|c|c|}
\hline Disability Categories & \multicolumn{2}{|c|}{ States } & \multicolumn{2}{c|}{ Percent of Responding States $^{\mathbf{a}}$} \\
\hline & 2009 & 2012 & $\begin{array}{c}2009 \\
(n=11)\end{array}$ & $\begin{array}{c}2012 \\
(n=25)\end{array}$ \\
\hline Specific learning disabilities & 9 & 22 & $82 \%$ & $88 \%$ \\
\hline Emotional disturbance & 8 & 21 & $73 \%$ & $84 \%$ \\
\hline Autism & 3 & 20 & $27 \%$ & $80 \%$ \\
\hline Other health impairment & 6 & 20 & $55 \%$ & $80 \%$ \\
\hline Speech language impairments & 6 & 18 & $55 \%$ & $72 \%$ \\
\hline Intellectual disabilities & - & 18 & - & $72 \%$ \\
\hline Orthopedic impairments & 3 & 16 & $27 \%$ & $64 \%$ \\
\hline Hearing impairments & 3 & 15 & $27 \%$ & $60 \%$ \\
\hline Traumatic brain injury & - & 14 & - & $56 \%$ \\
\hline Deafness & 2 & 14 & $18 \%$ & $56 \%$ \\
\hline Visual impairment & 3 & 1 & $27 \%$ & $4 \%$ \\
\hline Deaf-blindness & 1 & 7 & $9 \%$ & $28 \%$ \\
\hline Developmental delays & - & 9 & - & $36 \%$ \\
\hline Multiple disabilities & 1 & 12 & $9 \%$ & $48 \%$ \\
\hline
\end{tabular}

Note: ${ }^{\text {a }}$ Multiple responses from each state permitted; therefore, percentages will total greater than $100 \%$.

How are online administrators and teachers made aware of students' disabilities and given access to IEPs? In answer to this question, only 13 of the 46 states responded, generally indicating that online personnel were provided IEPs and other information about their students with disabilities through the same process as any local education agency receives this information (e.g., a state data system or e-mail). The other 33 states did not answer this survey question.

\section{Issues that Affect States' Abilities to Provide Free and Appropriate Public Education in a Least Restrictive Environment}

Finally, the survey gave the states an opportunity to reflect on current issues as well as to anticipate possible barriers to students with disabilities participating in online learning. Thirty-nine states responded to the following open-ended question: What are the top two or three issues that have arisen or that you see arising that will affect your state's ability to provide a free appropriate public education in the least restrictive environment for students with disabilities who are served in online environments?

As with the NASDSE survey, provision of related services was cited as a concern by 15 of the 39 responding states. Frequently, the concern was expressed as a coordination issue between online providers and related service providers.

Six states mentioned that providing accommodations for students with disabilities in online learning environments was an issue. This issue is interesting in light of the fact that 18 states cited the flexibility of instructional methods and schedules (both of which are specific forms of accommodation) as driving forces in the rationale for districts to offer online environments for their students in general.

Six states noted that monitoring the quality of special education services was particularly difficult and, when done, disconcerting. For example, one state recently monitored a local school district with a relatively large virtual school population and "almost no students [with disabilities] were receiving all the necessary supports" specified on their IEPs.

Although only one state reported that online providers were "requiring, requesting, or insinuating that students with disabilities must revoke access to their special education services in order to participate in 
an online program," the issue is worth noting here. The guidance documents from one state directly addressed this particular issue as well by stating "nor may the district ask the parent to revoke consent for special education service as a condition of acceptance."

Other issues that states mentioned were: provision of services to students with emotional disturbance and significant intellectual disabilities $(n=8)$; the technology infrastructure, including access to broadband $(n$ $=7)$; difficulty in defining what the least restrictive environment means in relation to online environments $(n=8)$; and conducting IEP meetings $(n=2)$.

\section{CONCLUSION}

The perspectives and concerns of $\mathrm{K}-12$ special education leaders seem to confirm Christensen et al.'s expectations about technology and cost drivers associated with growth in $\mathrm{K}-12$ online learning as it supplants traditional forms of education (e.g., online learning as an alternative form for credit recovery courses and other dropout prevention programs). Special education policies, no doubt, have incrementally adapted to support these current applications of technology. However, as more elementary and secondary level students with a wider array of disabilities participate in online learning (see table 1), special education policies and practices will come under even more pressure to provide a free appropriate public education in the least restrictive environment within the online general education curriculum. Lessons learned from higher education experiences may help K-12 leaders carefully craft policies to ensure the needs of students with disabilities are met.

The survey data indicate that ambiguity and variability exist in cross-state policies as well as in roles and responsibilities for providing special education and related services to students with disabilities in online environments, perhaps because each state is in a different stage of adopting this new approach to education. As a result, students bring to their undergraduate education a wide array of perceptions, attitudes, and prior experiences that may affect their learning outcomes [1, 2]. Without proper implementation and state and local guidance based on best practices, at some point access to online learning may become a civil rights issue that will require federal guidance and safeguards to ensure free appropriate public education in the least restrictive environment, and that students with disabilities receive all the educational benefits afforded by the technology in an equally effective and equally integrated manner. However, such guidance cannot ensure education benefits for student with disabilities in online learning environments unless and until empirical research answers such questions as, how do students with disabilities educationally benefit from online learning environments? What are the differences in such benefits among disability types? What accommodations can be made to online learning environments that result in equally effective and equally integrated use of the technology? More research is needed to answer these questions.

\section{REFERENCES}

1. Haverila, M. Factors Related to Perceived Learning Outcomes in an Undergraduate E-learning Course. International Journal of Knowledge and Learning, 6(4): 308-328 (2010).

2. Haverila, M. Prior E-learning Experience and Perceived Learning Outcomes in an Undergraduate E-learning Course. Journal of Online Learning and Teaching, 7(2): 206-218 (2011).

3. Picciano, A., and Seaman, J. K-12 Online Learning: A survey of school district administrators. Needham, MA: The Sloan Consortium, 2007.

4. Watson, J., Murin A., Vashaw, L., Gemin, B., and Rapp, C. Keeping Pace with K-12 Online \& Blended Learning. Evergreen Consulting, iNACOL (2012). www.KPK12.com.

5. Clark, T. Virtual Schools: Trends and Issues. Phoenix, AZ: WestEd Distance Learning Resource Network, 2001. 
6. Saul, S. Profits and Questions in Online Charter Schools. New York Times (December 12, 2011). http://www.nytimes.com/2011/12/13/education/online-schools-score-better-on-wall-street-than-inclassrooms.html?_r=1\&pagewanted=all.

7. Christensen, C., Horn, M., and Johnson, C. Disrupting Class. New York: McGraw-Hill, 2008.

8. Ahn, J. Policy, Technology, and Practice in Cyber Charter Schools: Framing the Issues. Teachers College Record, 113(1): 1-26 (2011).

9. Picciano, A., Seaman, J., Shea, P., and Swan, K. Examining the Extent and Nature of Online Learning in American K-12 Education: The Research Initiatives of the Alfred P. Sloan Foundation. Internet and Higher Education, 15: 127-135 (2012). doi:10.1016/j.iheduc.2011.07.004

10. U.S. Department of Education, Office of Civil Rights. Dear Colleague Letter (2010). http://www2.ed.gov/about/offices/list/ocr/letters/colleague-20100629.html.

11. Szpaller, K. Disabled UM Students File Complaint Over Inaccessible Online Courses. The Missoulian (September 18, 2012). http://missoulian.com/news/local/disabled-um-students-filecomplaint-over-inaccessible-online-course-components/article_d02c27ac-0145-11e2-bc26001a4bcf887a.html.

12. Joly, K. Web Accessibility: Required, Not Optional. University Business (August 8, 1996). http://www.universitybusiness.com/article/web-accessibility-required-not-optional.

13. Parry, M. Colleges Lock Out Blind Students Online. The Chronicle of Higher Education (December 12, 2010). http://chronicle.com/article/Blind-Students-Demand-Access/125695/.

14. Associated Press. Virginia University Named in Lawsuit Alleging Poor Access for Disabled. Diverse Issues in Higher Education (February 15, 2011). http://diverseeducation.com/article/14766/.

15. Müller, E. Serving Students with Disabilities in State-level Virtual K-12 Public School Programs. Alexandria, VA: Project Forum, National Association of State Directors of Special Education, 2009.

\section{ACKNOWLEDGEMENT AND ABOUT THE AUTHORS}

The data and analyses in this paper are products of the Center on Online Learning and Students with Disabilities, a grant from the Office of Special Education Programming, US Department of Education \#H327U110011. However, the contents do not necessarily represent the policy of the US Department of Education, and you should not assume endorsement by the federal government. Project Officer, Celia Rosenquist.

Paula J. Burdette, Ph.D., a director at the National Association of State Directors of Special Education, is a project director for the Center on Online Learning and Students with Disabilities.

Diana Greer, Ph.D., an assistant research professor at The University of Kansas Center for Research on Learning, is a project director for the Center on Online Learning and Students with Disabilities.

Kari L. Woods, MBA, a program associate at The University of Kansas Center for Research on Learning, is responsible for dissemination of findings from numerous sponsored research projects. 